用する事によって全身殊に手部の被儤を防ぐようにし

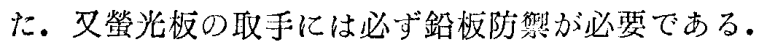

\section{（4）X線技師の被暴 X線量}

従来間接撮影は技師の $\mathbf{X}$ 線障害の原因として重視さ れて来たが，無防娒で操作すると撮影 1名につき0.5m の被濝をうける事になり約100名で1日の許容線量に達 してしまい 500－2,000 名の闆接撮影では如何に大量 の被瞅をうけるか惟然たるものがある技阿は必ず防䍀 衡立を用いるへきである，又直按撮影時に泣く子供の 体位固定, 蒾科口内撮影のフィルム固定，各種造影撮 影時及び重症患者各種撮影時の位置とフィルム固定等 の際に直接㳟射を被る事は極力避けなければならな い.とれは技師の右腕関節部の被儤の多い事及び主と して体位固定に従事した技印に被儤の多い事からも立 分推定出来る。尚技師は前述の如く操作室に散乱 $\mathbf{X}$ 線

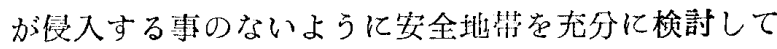
每日少量ずつの被儤をうける事のないように留意しな けれ代ならない，不断の注意と工夫こによって 1 週間

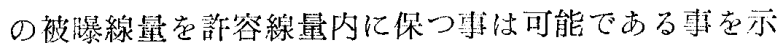
した。

（5）透視の時間及び人数について

\section{石川 支 部}

\section{○役蕒改選}

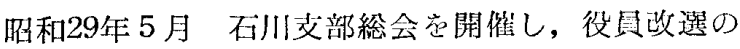
結果昭和29年度幹事に下記の各看が選出さる。

支 部 長 松田繁司

副支部長 浅井升知

幹事和田専一, 并松将英, 越村与四男,

南 純次

\section{京都 支 部}

\section{○支部総会}

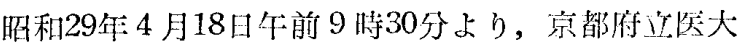
臨東講堂にて開催。千後 2 時より「オートラヂオグラ フに就いて」と題して富士フィルム古関靖夫技㸝の特 別講演並に富士フィルム提供の天然色映画「感光材料 の製造工程」その他の吹写があった。支部長に福岡太 郎, 副支部長に梅香家弥一が選举せられ, 幹事に陌村 信男, 吉田弘, 今津弘, 小會佐助, 百田秀治, 中川淳美, 沢田武夫，千原媣志，韵野巧，大標龍馬，福本照夫，

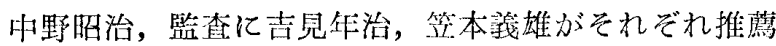
せられた。

\section{$\diamond 5$ 月研修会}

炤和29年 5 月19日午後 2 時より府立医大講堂で開猚 1.視神経管撮影に就いて（第2報）

京大腿科 高本雄一郎

吾々は透視時の医印の被曝を極力避ける為に上述の 如く䍃を用いているが透視人員が或る程度以上になる と許容線量を超過する。現在内利にて透視に従事する 医印は 1 週 1 回の被儤を原則としているが，反張りそ の他に 1 2 回の短洔間透視を余儀なくされる事が多 く, 従って現在の如く胸部60名前後胃部は 30 - 20 名 の透視は多猧ぎる，又1名の透視時間の短縮を計る為

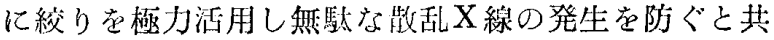
に不必琴な照射は中断すべきである。吾々は医的の各 人の 1 週間の透視人員は現在の $1 / 2$ 以下即ち脑部 25 名 以内又は罡部10名以内程度に娍じたいと考えている。

\title{
（V）結論
}

吾々はポケット線量計及びフィルムバッチ法を用い てX線室の各作業時の散乱X線定測定し又実際に診療 に従事している时の医解技的の被暴X線量を测定した その絈果不用意に敞乱X線に膜らされている場合が意 外に多い拢を発芫しその刘策を檄て具体的な方法によ つて㒛容線量内に止める事が出来た。

終りに御指導を賜った電気試験所放射線課村主進先 生並に東京医大榄木四郎助教授及び御授助を賜った杤 木県衛生部に深く感谢与る。

\section{$\diamond 6$ 月研修会}

6 月 12 日午後 2 時より府立医大膵堂で開催

1.X線管球並に整流管の寿命に就いて

神分工業 吉田輝雄技婂

2.腰惟の一撮影法 府立医大放射線科 平开考次 $\diamond 7$ 月研修会

7 月10日4:後 2 時より府论医大講堂で開催

1. 断面撮影法之断面観察法 大日本レントゲン 丹羽解部長

2.肺野の近接照準撮影に就いて 京都鹤生園 小金住助

\section{○8月研修会}

9 月11日4後 2 時より府近除大講堂で開催

1. 感光材料古近談 小西六写真工業 上田史郎技㿟

2.フィルムバッヂ・ロジメーターについて 市立中央市民病院 吉田弘

\section{大 分 支 部}

\section{○支部臨時総会}

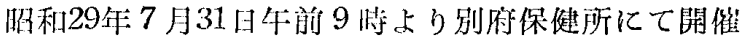
し，下記を聴請。胎和291F度支部役貴として，支部長 に安部正人君。幹事は藤延益見，大谷武雄，宇都宮博 各君決定.

1. 原子物理

2. 感光現像理論及び実際

3. 高王撮影機について
大分大学 黒 瀬 教 授 さくらフィルム技師 東芝医療技師 